\title{
PERANAN HEART RATE TERHADAP KUALITAS CITRA PADA PEMERIKSAAN CT ANGIOGRAPHY CARDIAC
}

\author{
Titin Susanti ${ }^{1}$, Arinawati ${ }^{2}$, Nanang Sulaksono ${ }^{3}$ \\ ${ }^{1,}$ Rumah Sakit Awal Bros Pekanbaru \\ ${ }^{2}$ Bapelkes Semarang \\ , 3 Poltekkes Kemenkes Semarang, Indonesia \\ Corresponding author: Titin Susanti \\ Email: titinsusanti070281@gmail.com
}

\begin{abstract}
Background: Cardiac angiography CT examination is a non-invasive measure to evaluate coronary blood vessels. Multislice CT with a high level of sensitivity and specificity is required to be able to reconstruct data from a constantly moving heart, resulting in diagnostic and informative image quality. Heart movement or heart rate plays a role in the occurrence of motion artifacts so that a stable heart rate is required at the time of data acquisition. The purpose of this paper is to see the role of the heart rate in cardiac CT Angiography examination and to determine the value of the heart rate to obtain the best image quality.
\end{abstract}

Methods: The research method uses a literature study approach by describing the article. Article searches use Science Direct, Radiopedia, American Journal Radiography, and Google Search to find articles that match inclusion and exclusion criteria so that 4 articles are obtained and then they are reviewed.

Results:: The study results show that the heart rate plays a very important role in producing image quality from CT examination. Cardiac angiography, a stable heart rate will minimize the occurrence of artifacts, which is one of the points in the image quality parameter. A stable heart rate to get the best image quality is at $\leq 60 \mathrm{BPM}$ when data acquisition with low heart rate variability

Conclusion: .Nilai heart rate untuk mendapatkan kualitas citra yang informatif dan diagnostik pada nilai heart rate $60 \mathrm{bpm}$, sehingga kualitas citra akan baik.

Keyword: Cardiac CT Angiography; Heart Rate; Image Quality; Artifacts

\section{Pendahuluan}

Jantung merupakan organ muskular berongga yang bentuknya mirip piramida dan terletak di dalam pericardium dalam mediastinum atau rongga dada. Jantung terbagi dalam empat ruang yaitu atrium dextra, atrium sinistra, ventrikel dextra dan ventrikel sinistra (Snell, 2012), jantung merupakan organ utama sirkulasi darah, serangkaian perubahan yang terjadi didalam jantung pada saat pengisian dan pengosongan darah disebut siklus jantung. Siklus jantung terdiri atas dua jenis yaitu kontraksi (systole) dan relaksasi (diastole) (Pearce, 2009). Siklus jantung digerakkan oleh otot-otot yang mendapat suplai darah dari arteri koronaria (Marieb, N, 2008).

Ada beberapa kelainan yang terjadi pada fungsi jantung, diantaranya : Coronary Artery Desease (CAD), heart failure, congenital heart desease, atrial and ventricular fibrillation (Marieb, N, 2008). Hasil riset kesehatan dasar tahun 2018 penyakit pada jantung masih merupakan penyebab kematian terbanyak setelah kanker. CAD yang diartikan penyakit jantung koroner terjadi karena adanya penebalan dinding pembuluh darah jantung (pembuluh darah koroner), yang terakumulasi dari lemak seperti kolesterol, trigiserida dibawah lapisan endothelium pada arteri koroner. Penebalan ini bisa terjadi di semua pembuluh arteri jantung dan menyebabkan terjadinya stenosis atau obstruksi. Sehingga pasokan darah yang dialirkan ke otot jantung terhalang, bila ini terjadi secara terus menerus maka jantung akan mati karena kekurangan suplai darah dan oksigen. Faktor resiko dari semakin banyaknya penderita jantung koroner adalah dislipedemia, kolesterol tinggi, diabetes, hipertensi, obesitas, merokok, stress psikososial, inaktivitas fisik, 
keturunan, proses penuaan, diet yang buruk (Zahrawardani dkk, 2013).

Untuk mengurangi resiko kematian karena penyakit jantung disebabkan stenosis dan arterosklerosis dapat dilakukan pemeriksaan non invasive seperti rontgen thorax, elektrokardiography (EKG), ultrasonography cardiac (echocardiography), treadmill, Computed Tomography (CT) cardiac dan Magnetic Resonance Imaging (MRI) cardiac (Ohnesorge, M, 2007). Pemeriksaan CT cardiac semakin baik mengikuti perkembangan teknologi, yang berdampak positif pada CT Angiography cardiac. Penggunaan 64-slice MSCT/MDCT atau lebih untuk pemeriksaan CT Angiography cardiac didukung oleh kecepatan rotasi yang berperan untuk meningkatkan resolusi temporal, slice collimation yang menurun untuk meningkatkan resolusi spasial, multi detector yang dikombinasikan dengan rekontruksi algoritma untuk mengurangi noise dan artefak (Achenbach dkk, 2012). CT Angiography cardiac merupakan prosedur pemeriksaan pembuluh darah arteri koronaria, yang menggunakan media kontras positif untuk menghasilkan gambaran pembuluh darah arteri koronaria. Pemeriksaaan ini memberikan informasi yang komprehensif mengenai lokasi, keparahan, dan karakteristik terutama karena stenosis dan arterosklerosis (Sun Z, 2012).

Rekonstruksi algoritma adalah prosedur matematis (algoritma) yang digunakan dalam merekontruksi gambar. Setelah detektor mendapatkan transmisi yang cukup, data dikirim ke komputer untuk proses selanjutnya. Setelah komputer melakukan proses rekonstruksi, gambar akan ditampilkan dan disimpan untuk nantinya dapat dianalisis ulang oleh monitor yang terhubung dengan konsul kontrol. Rekonstruksi algoritma yang dipilih semakin tajam, maka resolusi citranya pun akan menjadi tinggi. Hal ini terjadi karena kemampuan filter dalam merekonstruksi pixel - pixel yang berdekatan akan semakin jelas perbedaanya sehingga gambaran tulang, soft tissue dan jaringan jaringan lainnya dapat dengan jelas dibedakan pada layar monitor (Seeram, 2016).

EKG merupakan alat untuk menilai heart rate atau denyut jantung yang merupakan jumlah denyut jantung per satuan waktu yang dipresentasikan pada bpm (beat per minute). Heart rate bisa cepat, bisa juga melambat, variasi yang berbeda tergantung dari aktifitas yang dilakukan dan setiap manusia tidak sama, ukuran normal dari heart rate $60-100 \mathrm{bpm}$. Heart rate merupakan faktor penting dalam pemeriksaan CT Angiography cardiac, yang dapat menimbulkan artefak motion bila nilai heart rate tidak stabil.
Artefak merupakan salah satu point dari parameter kualitas citra selain noise, spatial resolusi dan contrast resolusi. Artefak yang ditimbulkan akan mempengaruhi kualitas citra yang dihasilkan, terutama artefak motion yang terjadi karena pergerakan jantung dan pernafasan. Untuk meminimalisir terjadinya artefak motion pada hasil CT Angiography cardiac diperlukan penggunaan EKG yang dikorelasikan dengan akuisisi scanning, bertujuan untuk mendapatkan hasil citra dari CT Angiography cardiac dengan optimal (Seeram, 2013). Kombinasi ECG Gating secara retrospektif dapat merekontruksi slice thickness sehingga dapat menghasilkan citra yang menilai arteri koronaria dengan baik (Sun, 2012, Fei \& Li, 2008).

Pada pemeriksaan CT Angiography cardiac sangat penting nilai heart rate yang stabil pada pasien, nilai heart rate yang terlalu tinggi dapat menunda dilakukannya pemeriksaan CT Angiography cardiac karena dapat menurunkan kualitas citra yang dihasilkan (Horiguchi dkk, 2011). Heart rate merupakan tanda vital dari jumlah denyut jantung permenit. Menurut American Heart Ascotiation (AHA) nilai heart rate normal 60-100 bpm. Nilai heart rate optimal untuk pemeriksaan CT Angiography cardiac di rentang 60-65 bpm pada saat akuisisi data. Untuk beberapa pasien diperlukan pemberian $\beta$-Blocker sebelum dilakukan CT Angiography cardiac, terutama pada pasien dengan nilai heart rate diatas $65 \mathrm{bpm}$ atau pasien dengan heart rate aritmia. Pemberian $\beta$-Blocker bertujuan untuk menurunkan nilai heart rate sehingga meminimalisir motion artefak untuk mendapatkan hasil yang informatif (Science dkk, 2006).

Studi literatur ini akan mengevaluasi heart rate pada pemeriksaan CT Angiography Cardiac, variasi nilai heart rate dan variabilitas nya selama dilakukan pemindaian, nilai heart rate yang digunakan untuk mendapatkan kualitas image terbaik dari pemeriksaan CT Angiography Cardiac.

Berdasar latar belakang beberapa jurnal yang penulis baca tersebut di atas, penulis tertarik untuk membuat kajian lebih lanjut dalam bentuk studi literatur dengan judul "Peranan Heart Rate Terhadap Kualitas Citra Pada pemeriksaan CT Angiography Cardiac

\section{Metode}

Jenis penelitian ini adalah penelitian kualitatif dengan pendekatan deskriptif menggunakan studi literatur secara komprehensif untuk menilai peranan heart rate terhadap kualitas citra pada pemeriksaan CT Angiography Cardiac. Penelitian studi literatur ini 
dilaksanakan dalam rentang waktu April sampai dengan Juni 2020.

Pengambilan data pada studi literatur ini dengan mencari jurnal - jurnal yang berkaitan dengan tema. Setelah mendapatkan jurnal kemudian menarik benang merah sehingga mendapatkan rumusan masalah. Studi literatur dilakukan melalui penelusuran dengan mesin pencari jurnal menggunakan kata kunci CT Angiography Cardiac, Heart Rate, Kualitas Citra, dan Artefak.

Setelah data didapatkan dibuat ringkasan dengan tabulasi. Kemudian dilakukan analisis data secara deskriptif komprehensif yang berisi kajian tentang persamaan, perbedaan dan melakukan kritisi berdasar pandangan penulis serta menyampaikan saran yang bisa diberikan.

\section{Hasil dan Pembahasan}

Pemeriksaan CT Angiography cardiac sangat dipengaruhi oleh nilai heart rate pasien selama akuisisi data berlangsung, bila nilai heart rate pasien tidak stabil akan menimbulkan motion artefak dan slap yang mempengaruhi kualitas citra yang dihasilkan serta informasi anatomi dari CT Angiography cardiac. Untuk meminimalisir terjadi nya motion artefak dan slap karena nilai heart rate yang tinggi atau tidak stabil sebelum dilakukan pemeriksaan pasien akan diberikan premedikasi berupa obat $\beta$-Blocker yang tujuannya untuk menurunkan nilai heart rate pasien.

Rekontruksi image dari alat CT scan juga mempengaruhi hasil, karena tidak semua generasi alat CT scan bisa digunakan untuk melakukan pemeriksaan CT Angiography cardiac, dibutuhkan CT scan dengan spesifik kemampuan yaitu kecepatan rotasi detector yang berperan untuk meningkatkan resolusi temporal, slice collimation untuk meningkatkan resolusi spasial, multi detector yang dikombinasikan dengan rekontruksi algoritma untuk mengurangi noise dan artefak.

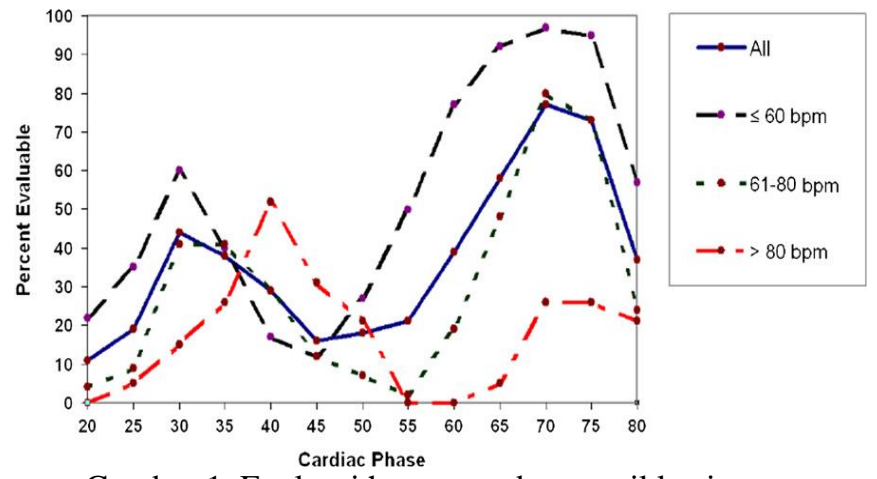

Gambar 1. Evaluasi heart rate dengan siklus jantung (Achenbach, dkk, 2012)
Artefak adalah kesalahan gambar yang tidak ada hubungannya dengan objek yang diperiksa. Artefak yang dapat timbul pada pemeriksaan CT ngiography cardiac disebabkan karena pergerakan pasien, pergerakan jantung (heart rate) dan pernafasan. Jika tidak dikoreksi akan menurunkan kualitas citra dan interpretasi image. Artefak yang disebabkan oleh pergerakan pasien yang dapat muncul berupa garis garis, data tumpang tindih dapat diminimalkan dengan pemberian edukasi pada pasien selama pemindaian untuk tetap tenang. Gerak yang ditimbulkan oleh pernafasan dapat diminimalkan dengan mengurangi waktu pemindaian dan tahan nafas selama pemindaian. Artefak yang ditimbulkan berupa bayangan ganda dari arteri koroner. Menggunakan metode helical merupakan cara efektif untuk mengurangi artefak karena pernafasan. Artefak logam yang disebabkan karena stent/ring koroner, alat pacu jantung, inplan kardioverter dan klip bedah menimbulkan artefak undersampling diperlukan peningkatan resolusi spatial untuk mengoreksinya. Dan artefak karena pergerakan jantung atau heart rate. Heart rate merupakan denyutan jantung persatuan waktu. Heart rate yang rendah dan lambat sangat penting untuk mendapatkan kualitas yang baik.heart rate yang tinggi akan menimbulkan kekaburan dan efeknya kan diperparah bila iramanya tidak teratur atau aritmia.

Berdasarkan kajian jurnal, kualitas citra yang dihasilkan berkaitan erat dengan peranan heart rate dan nilai dari variabilitas heart selam pemindaian berlangsung.

\section{Peranan Heart Rate Terhadap Kualitas Citra}

Peranan heart rate terhadap kualitas image menunjukkan korelasi yang signifikan, terutama variasi heart rate pada saat pemindaian atau akuisisi data. Meskipun penyakit yang mendasari adalah faktor penting yang mempengaruhi heart rate dan variabilitas heart rate, ada beberapa faktor lain yang mempengaruhinya. Seperti tahan nafas saat pemindaian, injeksi media kontras positip, pemberian $\beta$-Blocker atau nitrogliserin, dan demografi pasien yang meliputi jenis kelamin, berat badan, usia. Menggunakan EKG digital yang sinkron dengan modalitas memudahkan pemantauan variasi heart rate selama pemindaian. Dengan pemberian $\beta$-Blocker secara oral 1 jam sebelum pemeriksaan CT bertujuan menurunkan heart rate untuk meminimalkan terjadinya artefak karena variasi heart rate kecuali pada pasien dengan kontra indikasi. Upaya tahan nafas selama pemindaian dapat menurunkan heart rate. 
Menurut Leschka (2008) keteraturan heart rate selama akusisi data mempunyai korelasi yang signifikan dengan kualitas citra dan informasi diagnostic. Kualitas citra dan informasi diagnostic yang optimal ditentukan oleh keteraturan dari denyut jantung. Penilaian kualitas citra dengan mengkatagorikan dalam beberapa poin yaitu : 1. Sangat baik ( tidak ada artefak dan evaluasi tidak terbatas); 2. Baik (artefak minor, kualitas diagnostic baik); 3. Memadai ( artefak sedang tetapi masih dapat diterima dan diagnostic); 4. Tidak evaluatif ( artefak berat yang merusak evaluasi yang akurat). Dari penelitian yang Leschka, dkk lakukan diperoleh hasil $45,9 \%$ untuk skor $1,37,8 \%$ untuk skor $2,14,7 \%$ untuk skor 3 dan 1,6\% untuk skor 4 . Heart rate dan variasinya akan dievaluasi pada baseline ( pernafasan normal), hiperventilasi (intruksi tarik nafas dalam) dan akuisisi data (tahan nafas). Pemberian $\beta$-Blocker sebagai upaya untuk menurunkan heart rate $\geq 70 \mathrm{bpm}$ pada evaluasi baseline sehingga fase diastole lebih panjang, gerakan jantung lebih minimal dan meminimalisir artefak. Dari evaluasi tersebut akan diperoleh heart rate pasien dan variabilitasnya masuk dalam katagori heart rate $\geq 65$ bpm dan heart rate $\leq 65 \mathrm{bpm}$, sehingga dapat dikomparatifkan, kemudian akan diperoleh nilai yang memberikan kualitas yang optimal dan diagnostic dari pemeriksaan CT Angiography cardiac. Dengan rekontruksi setiap segmen arteri koroner untuk mendapatkan kualitas citra yang baik, secara signifikan

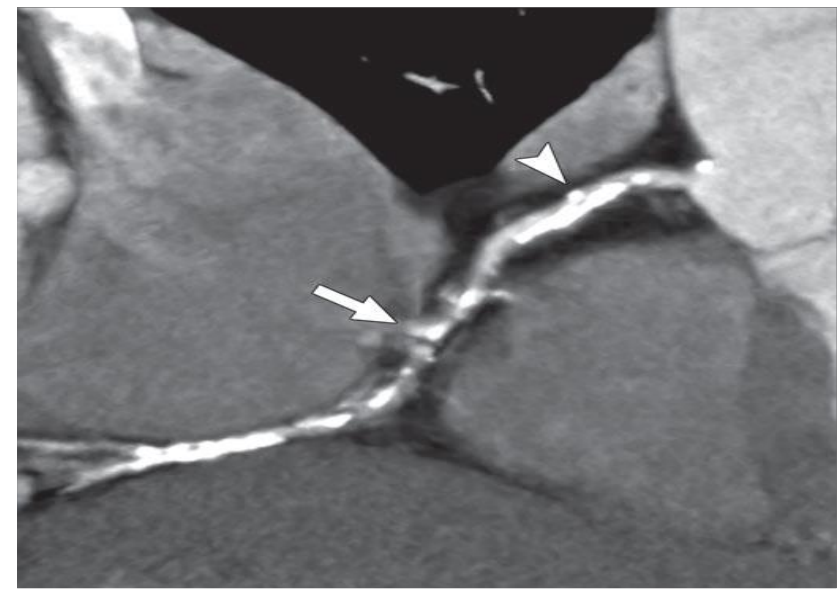

diperoleh pada pasien dengan heart rate $60 \mathrm{bpm}$ atau kurang.

Gambar 2. hasil non invasive (Leschka dkk, 2008)

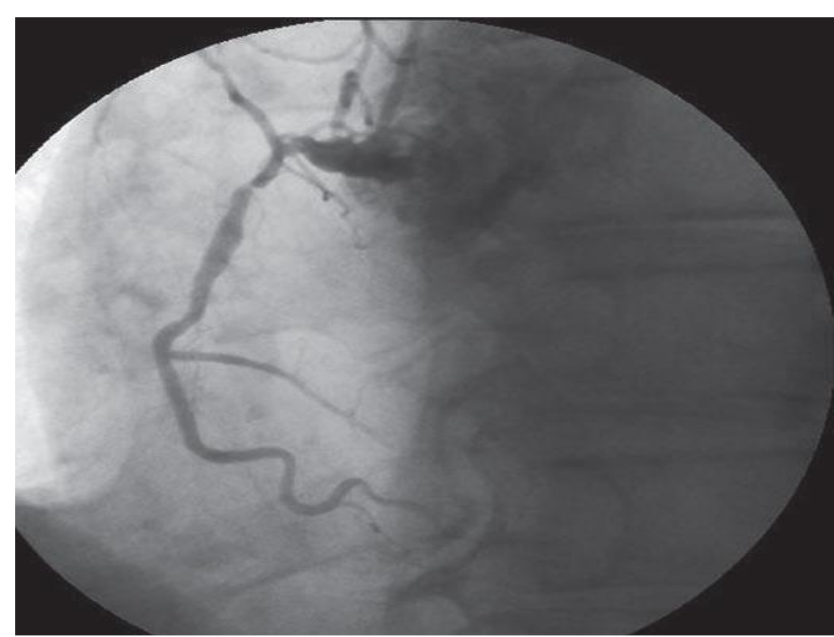

Gambar 3. hasil invasive (Leschka dkk, 2008)

Data yang dianalisis akan diberikan penilaian berdasarkan artefak yang timbul dari hasil rekontruksi data dan image dalam tiga katagori, yaitu :

1. Tidak artefak karena pergerakan.

2. Minimal artefak tetapi lumen arteri masih tervisualisasi jelas.

3. Kabur atau artefak yang membuat rancu visualisasi lumen atau stenosis.

Evaluasi pada semua pasien yang dikelompokkan sesuai heart rate dengan siklus jantung pada fase sistolik dan diastolic.

Pada penelitian ini pasien dengan heart rate diatas 60 bpm diberi Blocker 1 jam sebelum pemeriksaan, dan bila heart rate tetap diatas $65 \mathrm{bpm}$ selama akuisisi scan dikatagorikan heart rate tinggi. Kualitas image yang dihasilkan dinilai dengan tiga point skala skor yaitu :

b. Skor 1 didefenisikan kualitas sangat baik dan diagnostik.

c. Skor 2 didefenisikan kualitas suboptimal tapi masih diagnostik.

d. Skor 3 didefenisikan kualitas rendah dan non diagnostik.

Rekontruksi multisegment dari data yang dihasilkan pemindaian memperbaiki kualitas image, artefak yang ditimbulkan oleh pergerakan jantung menjadi minimal pada heart rate diatas $65 \mathrm{bpm}$. Hasil skor penilaian pada point suboptimal dan masih diagnostik. Kualitas image yang dihasilkan seperti pada gambar 4.6 yang ditunjukkan pada gambar a merupakan pria usia 67 tahun dengan heart rate $60 \mathrm{bpm}$ menggunakan metode EKG resrospektif skor penilaian adalah 1. Dan pada gambar b pria 69 tahun dengan heart rate $70 \mathrm{bpm}$ skor penilaian adalah 2 . 


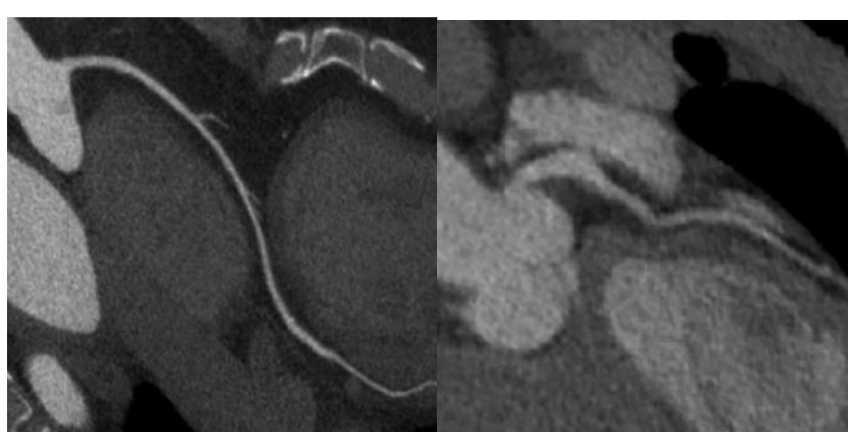

Gambar 4. Kualitas image yang dihasilkan (Lee dkk, 2011)

Heart rate mempunyai peranan yang sangat penting untuk mendapatkan hasil pemeriksaan yang berkualitas diagnostik dan informatif. Heart rate merupakan nilai dari denyut jantung yang terus bergerak mengikuti siklus jantung, dan pergerakan ini perlu disinkronkan dengan modalitas CT scan untuk mendapatkan hasil yang optimal. Heart rate yang stabil akan meminimalisir munculnya artefak pada hasil rekontruksi data scan. CT Angiography cardiac rentan terhadap artefak, artefak mengaburkan kondisi patologis, kegagalan mengenali artefak dapat menyebabkan underdiagnosis dan overtreatment, keduanya terkait dengan morbiditas dan mortalitas pasien.

Menurut penulis artefak dalam pemeriksaan CT Angiography cardiac karena pergerakan terutama pergerakan jantung yang terekam dalam nilai heart rate dapat diminimalisir karena artefak yang banyak akan mengurangi kualitas image yang dihasilkan dan berakibat hasil pemeriksaan tidak diagnostif / informatif sehingga mengakibatkan kerancuan pada dokter klinisi. Evaluasi heart rate sangat penting dilakukan karena heart rate mempunyai peranan utama dalam menentukan kuaitas citra yang dihasilkan, sehingga image yang dihasilkan optimal, diagnostik dan informatif.

\section{Nilai Heart Rate Pada Pemeriksaan CT Angiography Cardiac}

Berdasarkan Leschka, dkk (2008) dan Achenbach, dkk (2012) kualitas image terbaik akan diperoleh pada heart rate $60 \mathrm{bpm}$ atau kurang. Pemberian $\beta$-Blocker untuk menurunkan heart rate menjadi kurang dari 65 $70 \mathrm{bpm}$. Dengan tujuan untuk menurunkan heart rate, memperpanjang fase diastole sehingga gerakan koroner menjadi minimal. Untuk heart rate rendah fase diastolic lebih memberikan hasil kualitas citra yang diagnostic. Menurut Huriguchi, dkk (2011) niai heart rate 50 -60 bpm. Untuk pasien dengan heart rate $\geq 60 \mathrm{bpm}$ diberikan oral $\beta$-Blocker. Kecuali pada pasien dengan kontra indikasi, dan pemberian semprotan nitrogliserin 5 menit sebelum pemeriksaan CT Angiography dilakukan dengan tujuan untuk melebarkan diameter arteri koroner. Heart rate selama pemindaian $65 \mathrm{bpm}$ atau kurang dan pada pasien heart rate $\geq 60 \mathrm{bpm}$ diberikan $\beta$ Blocker sebelum dilakukan CT Angiography kecuali pada pasien kontra indikasi. Pasien yang gagal mencapai heart rate kurang dari atau sama dengan 65 bpm dimasukkan dalam kelompok termasuk kedalam kelompok heart rate tinggi.

Dalam literature "Multi-Slice $C T$ in Cardiac Imaging" oleh (Ohnesorge, $\mathrm{M}$, 2007) nilai heart rate pada saat akuisisi data yaitu $<65 \mathrm{bpm}$, pasien tahan napas dan pengatuan Pitch 1,5 pada satu siklus jantung untuk mendapatkan kuaitas terbaik. Menurut penulis nilai heart rate yang efektif untuk mendapatkan kualitas citra yang terbaik pada pemeriksaan CT Angiography cardiac yaitu $\leq 60 \mathrm{bpm}$ dengan variabilitas yang rendah.

\section{Simpulan}

Dapat diambil suatu kesimpulan dari penjabaran diatas, bahwa :

1. Peranan heart rate pada pemeriksaan CT Angiography cardiac sangat penting untuk menghasilkan kualitas citra yang baik. Heart rate sangat berpengaruh terhadap timbulnya artefak, artefak yang ditimbulkan oleh heart rate akan menimbulkan under interpretasi sehingga mempengaruhi kualitas citra yang dihasilkan pada pemeriksaan CT Angiography cardiac.

2. Nilai heart rate untuk mendapatkan kualitas citra yang informatif dan diagnostik pada nilai heart rate $60 \mathrm{bpm}$ atau kurang dengan tujuan yaitu untuk mendapatkan segmen terbaik dari arteri koroner dan kualitas citra rata rata terbaik pada nilai tersebut. Pada nilai 50- 60 bpm dengan tujuan untuk memperoleh rekontruksi arteri koroner di mid diastole, pada rentang ini diharapkan dapat memperoleh kualitas citra terbaik. Nilai heart rate 65 bpm atau kurang pada saat akuisisi data dengan tujuan bebas dari efek artefak gerak.

\section{Daftar Pustaka}

Achenbach, S., Manolopoulos, M., Schuhbäck, A., Ropers, D., Rixe, J., Schneider, C., Krombach, G. A., Uder, M., Hamm, C., Daniel, W. G., \& Lell, M. (2012). Influence of heart rate and phase of the cardiac cycle on the occurrence of motion artifact in dual-source CT angiography of the coronary arteries. Journal of Cardiovascular Computed Tomography, 6(2), 91-98. 
https://doi.org/10.1016/j.jcct.2011.11.006

Fei, X., \& Li, K. (2008). Vascular Attenuation on Detection. July, 43-49. https://doi.org/10.2214/AJR.07.2653

Horiguchi, J., Yamamoto, H., Arie, R., Kiguchi, M., Fujioka, C., Ohtaki, M., Kihara, Y., \& Awai, K. (2011). Is It Possible to Predict Heart Rate and Range during Enhanced Cardiac CT Scan from Previous Nonenhanced Cardiac CT? 24(4), 688-693. https://doi.org/10.1007/s10278-010-9333-2

Lee, A. B., Nandurkar, D., Schneider-Kolsky, M. E., Crossett, M., Seneviratne, S. K., Cameron, J. D., \& Troupis, J. M. (2011). Coronary image quality of 320-MDCT in patients with heart rates above 65 beats per minute: Preliminary experience. American Journal of Roentgenology, 196(6), 729-736. https://doi.org/10.2214/AJR.10.5252

Leschka, S., Scheffel, H., Husmann, L., Gämperli, O., Marincek, B., Kaufmann, P. A., \& Alkadhi, H. (2008). Effect of decrease in heart rate variability on the diagnostic accuracy of 64-MDCT coronary angiography. American Journal of Roentgenology, 190(6), 1583-1590. https://doi.org/10.2214/AJR.07.2000

Marieb, N, E. (2008). Human Anatomy. In S. Beauparlant (Ed.), Human Anatomy (Eighth). Pearson. https://doi.org/10.1016/c2009-0-35979-6

Ohnesorge, M, B. (2007). Multi-slice and Dual-Source CT in Cardiac Imaging (Second). Springer.

Pearce, evelyn c. (2009). Anatomi dan Fisiologi untuk Paramedis.

Science, R., Hopkins, J., \& Institutions, M. (2006). $\beta$ Blockers for Cardiac CT: A Primer. June. https://doi.org/10.2214/AJR.04.1944

Seeram, E. (2013). CT Physical Principles, Clinical Applications, and Qulity Control. In Journal of Chemical Information and Modeling (Third, Vol. 53, Issue 9). Saunder Elsevier. https://doi.org/10.1017/CBO9781107415324.004

Snell, richard s. (2012). Clinical Anatomy by Regions, Ninth Edition (Ninth). http://thepoint.lww.com/snell9e

Sun, Z. (2012). Coronary CT angiography with prospective ECG-triggering: an effective alternative to invasive coronary angiography. 2(11), 28-37. https://doi.org/10.3978/j.issn.2223-3652.2012.02.04

Sun Z, N. K. (2012). Multislice CT angiography in cardiac imaging. Part II: clinical applications in coronary artery disease. 51(4), 282-289.

Zahrawardani, D., Herlambang, K. S., \& Anggraheny, H. D. (2013). Analisis Faktor Risiko Kejadian Penyakit Jantung Koroner di RSUP Dr Kariadi Semarang TheAnalysis of Risk Factors of The Case of Coronary Heart Disease at RSUP Dr Kariadi Semarang Korespondensi : 1(2), 13-20. 